\title{
Golimumab in radiographic and nonradiographic axial spondyloarthritis: a review of clinical trials [Corrigendum]
}

Toussirot E, Vauchy C, Binda D, Michel F. Drug Des Devel

Ther. 2016;10:2087-2094.

On page 2089, a column heading in Table 1 was incorrectly presented. The last column heading was presented as "Golimumab $60 \mathrm{mg}$ ", whereas this should have been presented as "Golimumab $100 \mathrm{mg}$ " as shown below:

Table I Proportion of ASAS20 responders in the GO-RAISE and GO-AHEAD studies

\begin{tabular}{llll}
\hline Study & Placebo & $\begin{array}{l}\text { Golimumab } \\
\mathbf{5 0} \mathbf{~} \mathbf{g}\end{array}$ & $\begin{array}{l}\text { Golimumab } \\
\mathbf{1 0 0} \mathbf{~} \mathbf{~ g}\end{array}$ \\
\hline $\begin{array}{l}\text { GO-RAISE, primary } \\
\text { end point at Week 14 }\end{array}$ & 21.8 & 59.4 & 60 \\
$\begin{array}{l}\text { GO-RAISE, 2 years } \\
\text { G }\end{array}$ & 38.5 & 60.1 & 71.4 \\
$\begin{array}{l}\text { GO-AHEAD, primary } \\
\text { end point at Week 16 }\end{array}$ & 40 & 71.1 & $\mathrm{NA}$ \\
\hline
\end{tabular}

Abbreviations: ASAS, Assessment of SpondyloArthritis international Society; NA, not available.

\section{Publish your work in this journal}

Drug Design, Development and Therapy is an international, peerreviewed open-access journal that spans the spectrum of drug design and development through to clinical applications. Clinical outcomes, patient safety, and programs for the development and effective, safe, and sustained use of medicines are the features of the journal, which

\section{Dovepress}

has also been accepted for indexing on PubMed Central. The manuscript management system is completely online and includes a very quick and fair peer-review system, which is all easy to use. Visit http://www.dovepress.com/testimonials.php to read real quotes from published authors. 